\title{
MIGRASI ORANG-ORANG MADURA DI UJUNG TIMUR JAWA TIMUR: \\ SUATU KAJIAN SOSIAL EKONOMI \\ Oleh: \\ Mudji Hartono 1
}

\section{Abstrak}

Tulisan ini bertujuan untuk mengungkapkan faktor-faktor penyebab orangorang Madura bermigrasi ke wilayah ujung timur Jawa Timur. Untuk membahas permasalahan tersebut, penulis menggunakan kerangka pikir push and pull dimana yang berusaha untuk mengungkap kondisi yang melatarbelakangi kehidupan para migran Madura, serta perkembangan ekonomi di daerah ujung timur Jawa Timur.

Kajian awal penulis menunjukkan bahwa faktor penyebab orang-orang Madura bermigrasi ke daerah Jawa Timur bagian timur adalah kemiskinan di Madura. Sementara itu Jawa Timur dijadikan daerah tujuan migrasi karena di daerah tersebut sedang dibuka perkebunan -perkebunan baru yang menguntungkan rakyat setempat maupun para migran. Di Jawa Timur bagian timur para migran memperoleh beberapa fasilitas fasilitas antara lain: tanah, hewan ternak untuk mengerjakan tanah, dan pembebasan pajak selama beberapa tahun. Kata kunci: migrasi, Madura, ujung timur Jawa Timur.

\section{Abstract}

This article was aimed to reveal the causes Maduranese migration to the east part of the East Java.Researcer used the push and pull mind frame what was explores the background of Maduranese livein their homeland and economic development of the part east of the East Java.

The early study shows that the cause factors migration of Maduranese people to East Java is the poverty of Madura.The Maduranese people choice East Java because clearing for planting that give advantage for them.Maduranese people had received some facilites such as: land, livestock, and free from taxation for several years.

Keyword: migration, Madura, the east part of East Java. 


\section{A. PENDAHULUAN}

Citra Pulau Jawa pada abad ke-19 adalah penduduknya mengalami kemiskinan, selain itu juga tingkat mobilitas sosial sangat tinggi terutama migrasi. Antara kemiskinan dan migrasi saling berhubungan. Kemiskinan terjadi di Kedu, Rembang, Bojonegoro, Surakarta, Yogyakarta, dan Madura. Berdasarkan teori,, penduduk yang mengalami kemiskinan biasanya melakukan migrasi untuk tujuan memperbaiki taraf hidupnya, di samping itu migrasi juga terjadi dari daerah padat penduduk ke daerah yang jarang penduduknya.

Di banyak daerah terjadi out migration antara lain: Kedu, Magelang, Rembang, Tegal, Kendal, Lumajang, Kediri, Madiun, Ponorogo, Yogyakarta, dan Madura. Sedangkan in migration terjadi di daerah ujung timur Jawa Timur, tepatnya di daerah Pasuruhan, Probolinggo, Bondowoso, Situbondo, Besuki, Asembagus, dan Jember.

Wilayah itu merupakan pusat migran, suatu kenyataan bahwa sebagian besar penduduk di beberapa daerah itu adalah etnis Madura dan hanya sedikit yang bisa berbahasa Jawa. 2 Daerah asal migran bukan saja dari Jawa Tengah dan Jawa Timur saja, melainkan juga datang dari Bali,

Yogyakarta, dan Sulawesi.

Daerah pelepas migran dari Jawa

Tengah antara lain: Kedu, Tegal, Kendal, Rembang dan Magelang,,

sedangkan dari Jawa Timur adalah Kediri, Madiun, Bojonegoro, Ponoro- go, dan Madura. 3 Kemiskinan di daerah pelepas migran itu tampak pada hasil rata -rata perkapita beras per tahunnya. 4

Migran terbesar berasal dari Madura, yang diperkirakan tiap tahunnya mencapai 20-40 ribu orang. Data ini berdasarkan laporan dari penguasa lokal Sumenep tahun 1857. 5 Jumlah tersebut belum termasuk orang yang meninggalkan pulau tersebut tanpa ijin. Perlu diketahui bahwa Sumenep dan Kalianget merupakan pintu keluar pulau Madura, orang-orang yang akan berlayar ke selatan melewati selat Madura terlebih dahulu datang ke Sumenep dan kemudian lewat Kalianget.

Oleh karena banyak orang Madura yang bermigrasi ke wilayah ujung timur Jawa Timur, maka jumlah orang Madura pada tahun 1930 yang tetap tinggal di pulau asalnya hanya sekitar 45\%. Hal ini menarik untuk dibahas, mengapa orang-orang Madura banyak yang bermigrasi ke Jawa Timur bagian timur. Pada tahun 1846 populasi orang Madura yang ada di pojok Jawa Timur berjumlah 498.273

3Lihat. Gelderen. Dalam koloniale Studien, VI, 1922, h.138. Kemiskinan daerah Kedu baca Nur Aini Setiawati (1998). Penduduk Kedu pada Abad XIX - Awal Abad XX Tinjauan Sosial Ekonomi. Lembaran Sejarah Vol 1 No. $21998 . \quad$ Tentang kemiskinan di Rembang, dan Bojonegoro. lihat. Mudji Hartono. Pertanian Tanaman Pangan di Karesidenan Rembang 1900-1928,Tesis tidak diterbitkan.Yogyakarta: UGM. 2002. Hlm. 135.

Mawarti Djoenet Poesponegoro. (1990). Sejarah Nasiona Indonesia. Jakarta; Depdikbud.,hal. 115.

TNI 'De Bevolking dicht heit van Java en Madura op het einde 1863' , hlm. 79-80. 
orang. $6 \quad$ Berikut diketahui bahwa Madura pada tahun 1863 telah men jadi daerah yang padat penduduknya.

Tujuan penulisan ini adalah untuk mengungkap faktor-faktor pe-nyebab migrasi orang-orang Madura ke daerah ujung timur Jawa Timur. Migrasi itu merupakan bagian dari sejarah orang Madura. Dengan demikian tulisan ini bertujuan untuk mengungkap bagian sejarah etnis Madura, dan sekaligus untuk mengkaji bagian sejarah demografi Indonesia, sudah tentu juga untuk menambah referensi tentang sejarah etnis Madura dan melengkapi tulisantulisan yang sudah ada.

Adapun tulisan yang sudah ada

antara lain: kuntowijoyo

Madura 1850-1940 perubahan sosial dalam masyarakat agraris, Edy Burhan Arifin (1997) migrasi orangorang Madura dan Jawa ke Jember suatu kajian historis komparatif, Huub de Jonge dalam empat jaman: pedagang, perkembangan ekonomi dan Islam suatu studi Antropologi Ekonomi, Aminuddin Kasdi (2003) perlawanan penguasa Madura atas hegemoni Jawa relasi pusat daerah periode akhir mataram (1726-1745), Depdiknas (2001) Peranan rakyat Besuki (jawa timur), Jos Hafid (2004) perlawanan petani; Kasus tanah Jenggawah, A. Subaharianto (2004) tantangan industrialisasi Madura (membentur kultur, menjunjung leluhur) malang bayu media publising.

$6 \mathrm{KV}, 1896-1911$.
Untuk menganalisis faktor penyebab migrasi orang-orang Madura ke Jawa Timur bagian timur itu digunakan kerangka pikir push and pull. Mengacu pada teori yang di kemukakan oleh Everette S Lee 7 tentang migrasi, bahwa migrasi disebabkan oleh 4 faktor yaitu:

1. Faktor yang ada di daerah asal dan faktor yang ada di daerah tujuan

2. Faktor ekonomi

3. Faktor pribadi

4. Faktor rintangan

Sesuai dengan faktor pertama, maka pushfactor menunjuk kepada

faktor yang ada di daerah asal sedangkan pullfactor menunjuk kepada faktor yang ada di daerah tujuan, yaitu daya dorong dan daya tarik. Daya dorong ialah faktor yang ada di daerah asal, sedangkan daya tarik ialah faktor yang ada di daerah tujuan, biasanya berhubungan dengan fasili-

tas yang disediakan oleh daerah tujuan. Faktor yang ada di daerah asal ini berhubungan dengan kondisi sosial ekonomi, keadaan tanah, ekologi, dan pekerjaan atau mata pencaharian penduduk, sedangkan

faktor yang ada di daerah tujuan berkaitan dengan fasilitas yang disediakan oleh daerah tujuan, seper-

ti lapangan pekerjaan, tanah, dan berbagai hal yang meringankan beban hidup para migrant dari Madura.

B. Kemiskinan Sebagai push Factor

Menurut Kuntowijoyo kemiskinan penduduk Madura disebabkan oleh

Sunarto Hs. SU.(1985) . Penduduk Indonesia Dalam Dinamika Migrasi 1971-1980.

Yogyakarta: Dua Dimensi, H.17. 
keadaan tanahnya yang tidak subur, kering, dan gersang. 8 Keadaan tanah di pulau Madura didominasi oleh deposit kapur. Pada lapisan atas berupa batu kapur, lapisan berikutnya berupa endapan kapur, dan di daerah pantai baik di utara, pantai barat ataupun di sepanjang pantai selatan berupa tanah aluvial pantai.

Di beberapa tempat terdapat tanah alu-vial sungai, yaitu di dekat kota Bangkalan, Sampang, Pamekasan, dan kota Sumenep. Keadaan tanah yang demikian mengakibatkan produktivitas tanah rendah, hasil setiap bau tanah berkisar antara 14,26 - 15 pikul, hasil ini jauh di bawah rata-rata produksi tanah di pulau Jawa yaitu, setiap bau tanah di jawa menghasilkan antara 24,17-27 pikul. Pendapatan perkapita beras penduduk Madura per tahunnya sangat kecil, pada 36 distrik yang ada di kabupaten Madura rata -rata penghasilan beras perkapita per tahun kurang dari setengah pikul. 9

Ukuran yang lain tentang kemiskinan adalah rendahnya konsumsi garam per orang/tahun. Konsumsi garam penduduk Madura per orang/tahun adalah; 2,26 kg. Hal ini masih di bawah rata-rata penduduk Pasuruan (2,52), Madiun $(3,28)$, Surabaya $(2,34)$, dan Kedu $(3,08) .10 \quad$ Menurut De Jonge pendapatan perkapita penduduk Madura

8 Kuntowijoyo. Madura 1850 -1940: Perubahan Sosial Dalam Masyarakat Agraris.h. 23.

9 Geldern. 'Bevolkings-dicchteid en Lanbouwop Java'.Koloniale Studien.h. 32-34

10 Parwoto. (1996). Monopoli Garam di Madura 1905-1820. Tesis tidak diterbitkan. Yogyakarta:UGM hal. 119. pada jaman kolonial adalah sepertiga dari pen-dapatan rata -rata perkapita penduduk Indonesia. 11

Sebagaimana diketahui bahwa sebagian besar penduduk Madura adalah petani yaitu sekitar 63\%. Di Madura pertanian yang ada adalah pertanian tadah hujan, atau disebut juga pertanian lahan kering, ciri pertanian ekologi Tegal. Pola kepemilikan tanah bukan komunal sehingga orang Madura tidak begitu terikat pada tanah. Keunikan Madura dasarnya karakteristik lingkungan dan budaya yang membuat banyak orang Madura bermigrasi ke Jawa Timur. 12

Proses dan pengaruh struktur ekologis mengantarkan Madura dalam suatu situasi kelangkaan ekonomi yang signifikan ditambah lagi dengan laju pertumbuhan penduduk yang tinggi. Menghadapi hal itu terjadi migrasi yang cukup besar di ujung timur Jawa Timur, ketika itu Jawa Timur sebagai pusat gula ekonomi, hal ini dapat diartikan bahwa daerah ujung timur Jawa Timur yang luasnya sekitar 17\% dari seluruh Jawa Timur merupakan sumber uang Sen atau gulden.

Pada masa kolonial daerah tersebut menjadi pusat aktivitas eko nomi, diperkirakan sekitar 49\% 13 berasal dari jawa timur apalagi pada saat itu di daerah tersebut sedang

dibangun proyek-proyek perkebunan

11 De Jonge. 1998. Dalam Empat Zaman Perdagangan: Perkembangan Ekonomi Islam.h.18- 23.

12 Kuntowijoyo, Op.cit.h 71

13 De Jonge, Op.cit., h.18-23. 
oleh pemerintah Belanda. De Jonge 14 menyebut bahwa daerah Jawa Timur bagian timur itu sebagai pusat "gula ekonomi". Karena kondisi geografis Madura yang tidak subur dan maraknya kemiskinan di sana, menyebabkan sebagian penduduk bermigrasi menuju ke daerah yang memiliki perekonomian yang tinggi di wilayah Jawa Timur bagian timur, Besuki merupakan salah satu jantung perkebunan tebu yang tumbuh sejak tahun 1840-an dan berkembang sampai abad berikutnya. 15

Sejarah Madura selama satu abad memperlihatkan saling berhubungan antara pengaruh faktor ekologi dengan pelaku sejarah dalam membentuk sebuah masyarakat. Kemiskinan dan keterbelakangan Madura merupakan sebagian akibat ketiadaan IPTEK serta sarana untuk mengolah potensi sumber daya Madura pada satu sisi dan ketidakmampuan Madura memanfaatkan peluang global dalam bentuk investasi untuk industrialisasi pada sisi yang lain. 16

Memang di Madura pernah dibuka industri perkebunan tembakau dan tebu, namun segera ditutup karena penduduk belum siap, oleh karena itu akibat minimnya kesempatan ekonomi maka mengakibatkan terjadinya pengangguran dan kemiskinan. Faktor tersebut menjadi penyebab utama terjadinya migrasi jangka panjang dari Madura ke wilayah lain untuk

\footnotetext{
${ }^{15^{14}}$ Ibid.

Sartono Kartodirjo dan Joko Suryo. Sejarah Perkebunan Indonesia: Kajian Sosial dan Ekonomi.Yogya -karta; Aditya Media. 1991. ${ }_{16}$ Kuntowijoyo,Op.Cit., h.24.
}

mencari penghasilan, faktor-faktor tersebut yang pertama berkaitan dengan latar belakang pendidikan modern masyarakat yang masih rendah, kedua terkait dengan kendala transportasi Surabaya -Madura. 17

C. Perkebunan di Karesidenan Besuki sebagai pull factor.

Dibukanya perkebunan di daerah ujung timur Jawa Timur menarik orang-orang Madura untuk bermigrasi menjadi buruh perkebunan dengan tujuan untuk mencari penghasilan, karena di Madura sulit untuk mendapat penghasilan dari kegiatan perkebunan dan pertanian karena terbentur kondisi alam yang jauh berbeda dengan Jawa. 18

Besuki merupakan daerah administrasi setingkat Karesidenan sejak masa pemerintahan Raffles. Wilayahnya terdiri dari kabupaten Panarukan, Besuki atau Demung, Situbondo, Bondowoso, Jember, Banyuwangi, Pasuruan dan Probolinggo. Besuki merupakan daerah yang subur. Secara geografis Besuki sangat menguntungkan untuk pertanian.

Sungai-sungai kecil yang tidak dapat dimanfaatkan untuk tranpotasi dapat digunakan untuk irigasi, deretan gunung-gunung berdampak positif bagi pertanian, wajarlah kalau banyak pengusaha Belanda yang tertarik untuk membuka usaha di daerah itu. Para pengusaha menyewa tanah hutan dan tanah kosong untuk mendapatkan lahan penanaman dan membuka perkebunan. Persewaan

17 De Jonge, 1998.h. 34

${ }_{18}$ Nawiyanto, hlm. 182 
tanah atau tanah er pacht pada tahun 1892 ada 29.000 bau dan tahun 1902 sudah mencapai 570.000 bau.

Pada akhir abad ke-18 Besuki masih jarang penduduknya dengan tingkat kepadatan mencapai, ratarata 200 orang/km2 jumlah penduduk tahun 1919/1920 ada 1.915.037 jiwa 19 maka untuk mengelola perkebunan dirasa sangat kurang. Sehingga kemudian didatang-kan tenaga kerja dari Madura. Ketika itu Madura lebih padat, yaitu: 200-300 orang/km2 mereka diberi petak tanah hutan untuk dibuka dan dimilikinya, berita tentang pembukaan perkebunan di Jember dan Besuki disebar luaskan pada masyarakat di Pulau Madura.

Setelah itu penanaman tem-bakau berkembang di Besuki dan daerah ujung timur yang lainnya. Di Besuki pengusaha asing membuka tanah berdasarkan er pacht dan membagibagikan kepada rakyat sebagai tanah garapan. Dengan kerjasama seperti itu rakyat mendapatkeuntungan serta mempunyai kesempatan meningkatkan kesejahteraan, oleh karena itu banyak orang Madura yang tertarik untuk bermigrasi di daerah itu. 20

Berita tentang pembukaan perkebunan, dan keberhasilan orang-orang Madura di tempat yang baru seperti di Jember segera menyebar ke masyarakat di Pulau Madura, mula-mula melalui kerabat dekat mereka, kemudian berita itu segera tersebar luas di lingkungan penduduk Madura pada akhirnya banyak orang Madura yang tertarik untuk bermigrasi ke daerah ujung timur Jawa Timur.

Berita tersebut berbunyi; siapa saja boleh membuka hutan di Jember dengan syarat sebagian tanah tersebut harus ditanami tanaman perdagangan, khususnya tembakau.

Selanjutnya orang-orang dari Sumenep datang ke Jember seperti di Lengkong dan Mumbulsari, Kedatangan mereka disusul oleh rombongan yang lain. 21

Pola migrasi orang-orang Madura adalah sebagai berikut: para migran datang ke tempat tujuan secara berkelompok kecil antara 10-15 orang, mereka melewati SumenepKalianget kemudian menyeberangi

Selat Madura singgah di pelabuhan Panarukan.

Selanjutnya dari Panarukan menuju Bondowoso atau Situbondo untuk menetap sementara di daerah pantai, kemudian mereka menuju Jember utara. Dari Jember utara terus ke Jember selatan, di Jember selatan mereka membuka hutan dan mendirikan desa-desa Madura seperti Jenggawah, Cangkring dan yang lain. Pada tahun 1806 diketahui telah ada desa-desa orang Madura, sama seprti yang didirikan di Jenggawah, Cangkring, Muktisari yang terletak di Jember selatan. Di Pasuruhan ada 3 desa, dan di Probolinggo ada 22 desa.

Tanah yang mereka buka digunakan untuk penanaman tem-

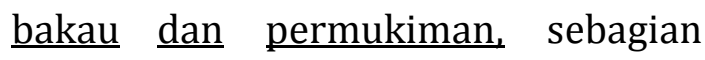

21 Jos Hafid. (2001). Perlawanan Petani, Kasus Tanah Jenggawah.Jakarta. Pustaka Latin., 
yang lain diusahakan oleh perusahaan dengan tanaman yang sama atau pembayaran di muka dari pembelian tembakau yang akan dihasilkan. Di Jember perkebunan swasta dibuka, perluasan lahan terjadi sejak akhir dasawarsa abad ke-19 sistem sewa tanah muncul setelah pengusahapengusaha baru merekrut petani yang umumnya orang Madura. orang-oang Madura sudah memiliki pengalaman dalam perkebunan tembakau dan tebu.

Di Jember terjadi pembukaan perkebunan secara luas. tahun 18581859, Bernie, Mathiesen, dan Gennep bekerja sama mengembangkan usaha perkebunan tembakau karena tanahnya dianggap cocok untuk budidaya tembakau Na-Oogs. Pada saat itu perusahaan perkebunan swasta mulai beroperasi di distrik Jember afdeling Bondowoso residensi Besuki. Awal penanaman ada di tegalan milik petani, kemudian Bernie memberikan fasilitas yang diperlukan petani, seperti bibit dan hewan ternak untuk menggarap lahan tetapi konskuensinya hasil panen diserahkan atau dijual kepada Bernie.

Saat itu pula pemerintah Belanda membangun infrastruktur jalan kereta api Jember-Klakah di sebelah barat dan Jember-Panarukan di sebelah timur, perlu diketahui bahwa tembakau Besuki, Na-Oogs dan tembakau Vostenlanden dikenal dengan nama tembakau jawa yang merupakan tembakau unggulan Hindia-Belanda sampai tahun 1940-an. 22

22 Sartono Kartodirjo dan Djoko Suryo. Op.Cit.
Di Besuki selain perkebunan tembakau juga dibuka perkebunan tebu dan kopi, perkebunan kopi mengawali rekrutmen tenaga kerja dari luar wilayah Karesidenan Besuki. Di

Besuki didirikan pabrik-pabrik gula, di Panarukan terdapat 12 buah pabrik gula, yaitu; pabrik gula Maas, Assembagoes, Panjie, Olean, Boedoen, Bedadoeng, Soekowidi, Prajekan dan Tangarang, Semboro, dan Goenoeng Sarie.

Di Besuki sendiri terdapat 5 buah pabrik gula, pemerintah Belanda menggalakkan penanaman kopi di Situbondo, Besuki, dan Jember barat, yaitu di Penanggungan sampai di Gambirono, tenaga kerjanya didatangkan dari Magelang dan Tegal. Pada tahun 1840 orang-orang Madura dari Pamekasan datang ke Ajung, Jember.

Para migran itu bukanlah migran permanen, mereka hanya tinggal selama 2 minggu sampai 1 bulan, ataupun 3 hingga 4 bulan. Pada tahun 1846 diketahui populasi orang Madura di Besuki dan sekitarnya ada 498.273 jiwa di Gresik, Surabaya dan Sedayu berjumlah 240,000 jiwa. Total orang Madura di ujung timur Jawa Timur ada 1.055.915 jiwa. 23

Besarnya arus migrasi mengakibatkan mobilitas di Selat Madura cukup tinggi karena ongkos berlayar hanya 25 sen, sedangkan upah buruh yang diterima di perkebunan kopi sebesar 30,35-40 sen mereka yang bekerja menjadi kuli angkut per hari di upah 25-30 sen/hari. Jadi bekerja

23 Jos Hafid. Op.cit, h.19. 
satu hari saja bisa dipakai untuk transpotasi ke jawa timur.

Migran permanen baru terlihat pada tahun 1930, pada tahun 1928 pemerintah Belanda membuka perkebunan tebu di Pasuruhan, yaitu di Kedawung, Pengkol dan Pleret. Pembukaan perkebunan di ujung timur Jawa Timur menjadi daya tarik para migran. Dibukanya perusahaan perkebunan di berbagai daerah di ujung Jawa Timur menarik orangorang Madura untuk bermigrasi dan menjadi buruh perkebunan dengan tujuan mencari penghasilan.

D. Kesimpulan

Faktor-faktor penyebab orangorang Madura melakukan migrasi ke daerah ujung timur Jawa Timur adalah :

1. Kemiskinan penduduk Madura, kemiskinan itu sebagai akibat dari keadaan alam yang tidak baik. Tanah pertanian di Madura tidak subur, tanahnya berupa kapur dan kuranganya air irigasi untuk irigasi, curah hujannya juga rendah karena itu, tingkat produktivitas tanah juga rendah dan minimnya kesempatan ekonomi, sehingga di Madura orang sulit mendapatkan penghasilan.

2. Pembukaan perkebunan-perkebunan besar menjadi daya tarik yang sangat kuat, perkebunan dapat memberikan kesejahteraan para pendatang yang sangat menguntungkan para migran dan perkebunan-perkebunan yang ada tidak memberatkan orang Madura, justru sebaliknya meringankan beban orang Madura. Perkebunan tembakau dan tebu tidak asing bagi orang Madura karena di Madura pernah dibuka perkebunan itu. Pertanian tembakau merupakan pertanian yang pokok di Madura perkebunan di ujung timur Jawa Timur merupakan lapangan pekerjaan bagi orang Madura. Perkebunan tersebut dibuka di Jember, Besuki, Situbondo, Bondowoso, Panarukan, dan Pasuruan. Wilayah ujung timur Jawa Timur menjadi sumber gulden, karena itu didatangi oleh banyak orang, termasuk etnis Madura. Dengan demikian, di ujung timur Jawa Timur orang Madura lebih mudah mendapatkan penghasilan daripada di tempat asalnya. Selain itu orang Madura mendapat pembagian tanah dan hewan ternak secara gratis untuk mengerjakan sawah dan para migran selama beberapa tahun dibebaskan dari pajak.

Pola migasi orang-orang Madura adalah para migran datang secara berkelompok kecil, berjumlah antara 10-15 orang. Mereka dari daerah di pulau Madura terlebih dahulu datang di Sumenep dan kemudian ke Kalianget, selanjutnya menggunakan perahu kecil berlayar menuju ke pelabuhan Panarukan. Setelah singgah beberapa lama kemudian melanjutkan perjalanan menuju Bondowoso, Situbondo. Mereka kemudian menetap di daerah pantai untuk sementara waktu, migran ini 
biasanya datang pada musim kemarau dan kembali lagi ke Madura setelah beberapa minggu, paling lama 4 bulan. Mereka bermigrasi untuk bekerja mencari penghasilan.

Dari Bondowoso, para migran menuju daerah Babatan di Jember Utara, dari daerah itu perjalanan dilanjutkan ke Jember selatan. Di Jember Selatan mereka membuka hutan dan bertempat tinggal secara menetap dalam jangka panjang. Di daerah itu, mereka bermigrasi untuk mencari tempat tinggal baru.

Daerah yang paling banyak dihuni ruhan ke timur sampai Banyuwangi orang Madura yang paling banyak terdapat di Situbondo, Bondowoso, dan bagian timur Probolinggo. Migrasi orang Madura terdiri dari dua jenis, yaitu: pertama adalah migrasi musiman, dan kedua adalah migrasi menetap.

DAFTAR PUSTAKA

Abdurachim. (1973). Pengantar Masalah Penduduk.Bandung: Alumni

Aminuddin Kasdi. (2003). Perlawanan penguasa Madura Atas hegemoni Jawa, relasi pusat daerah periode akhir Mataram 1726-1745.Yogyakarta: Jendela..

De Jonge. (1998). Dalam empat zaman, Perdagangan, Perkembangan Ekonomi, Islam.Jakarta Gramedia,

(1990). Subsistensi, Komersialisasi, Industrialisasi, Jember: Pusat Kajian Madura, Universitas
(1995). Ziarah, Garam, Aduan Sapi. Yogyakarta. LKIS.

Edy Burhan Arifin. (1997). Migrasi orang-orang Madura dan Jawa ke Jember.Jakarta: Depdikbud

Geldern J. Van. (1922) 'Bevolkingsdicchteid en Lanbouwop Java'. Koloniale Studien. VI.

Ida Bagus Mantra. 2003. Demografi Umum. Yogyakarta; Pustaka Pelajar.

Jos Hafid. (2001). Perlawanan petani, kasus tanah Jenggawah.Jakarta: Pustaka Latin.

Kuntowijoyo. (1992). Madura 18501940, Perubahan Sosial Dalam Masya-rakat Agraris.Yogyakarta: Pustaka Pelajar.

Marwati Djoenet Poesponegoro. (2008). Sejarah Nasional Indonesia.Jakarta Depdikbud, Balai Pustaka.

Mudji Hartono. (2002) Pertanian Tanaman Pangan di Karesidenan

diterbitkan.Yogyakarta: UGM

Nawiyanto. (2009). Pertumbuhan Penduduk Besuki Kajian Historis. Humaniora Vol.21 No.2,2009.

Madura 1905-1920, Tesis tidak diterbitkan. Yogyakarta: UGM

Sartono Kartodirdjo dan Djoko Suryo. Indonesia, Kajian Sosial Dan Ekonomi. Yogyakarta; Aditya Media. 
Ricklefs, Mc. (1991). Sejarah Indonesia

Modern.Yogyakarta: Gajah Mada

University Press.

Sunarto Hs. (1985). Penduduk Indo-

nesia Dalam Dinamika Migrasi 1971-

1980. Yogyakarta: Dua Dimensi. 
